\title{
Honey production by Africanized and European honey bees in Costa Rica
}

\author{
M. Spivak ${ }^{*}$, S. Batra ${ }^{2}$, F. Segreda ${ }^{3}$, A.L. Castro ${ }^{3}$, and \\ W. Ramírez 3 \\ 1 Department of Entomology, University of Kansas, Lawrence, KA 66045, USA; \\ 2 USDA-ARS, Beltsville Agricultural Research Center, Beltsville, MD 20705, USA; \\ 3 Universidad de Costa Rica, Ciudad Universitaria, Costa Rica
}

(received 15 June 1988, accepted 24 February 1989)

Summary - Seventeen colonies of bees were used in a test of honey production in a coffee plantation in Costa Rica. The identities of the colonies were not known at the beginning of the experiment. Behavioral identifications were made in the field as to whether a colony was 'strongly Africanized', 'strongly European' or 'intermediate'. The distance spanned by 10 linear worker cells was also measured in the field. Morphometric analyses, conducted independently, identified colonies as probably Africanized or probably European. Although the 'intermediate' category tended to produce more honey, there was no significant difference in honey production between bee types, whether sorted by behavior or morphometrics. There was no significant correlation between initial colony weight or brood area and total amount of honey produced. Appropriate uses of behavioral and morphometric identifications are discussed.

\section{Apis mellfera - honey production — africanized honeybee - Costa Rica}

Résumé - Production de miel par les abeilles africanisées et les abellles européennes au Costa Rica. Cette étude décrit la production de miel dans une plantation de caféiers au Costa Rica de mars à mai 1986, trois ans après l'arrivée dans ce pays des abeilles africanisées. L'identité des colonies n'était pas connue au début de l'expérience. Les valeurs initiales du poids des colonies et de la surface du couvain ont été prises avant la miellée principale. Chaque colonie a été identifiée sur le terrain par une estimation du comportement et par la mesure de la distance couverte par 10 cellules d'ouvrières. L'identification au laboratoire, basée sur l'analyse morphométrique, a été réalisée indépendamment une fois l'étude fínie.

L'estimation du comportement a été faite en classant chaque colonie en afortement africanisée» (FA), «fortement européenne» (FE) et aintermédiaire» (Int). Les critères de classification dans la catégorie FA ont été l'agressivité (plus de 10 piqûres reçues par visite) et lirritabilité de la colonie. Les colonies FE étaient généralement dociles (0-2 piqûres par visite) et calmes. Les colonies étaient classées comme intermédiaires si elles n'étaient ni franchement agressives ni douces et si la réaction de piqûre pouvait être contrôlée par des manipulations attentives. On a mesuré la distance de 10 cellules d'ouvrières sur des rayons construits naturellement (non à partir de cire

\footnotetext{
- Present adress : USDA, Carl Hayden Bee Research Center, 2000 E. Allen Road, Tucson, AZ 85719 USA.
} 
gaufrée). Le programme de morphométrie «l.D. Bees», qui utilise un analyseur d'image, différencie les abeilles africanisées des européennes d'après les mesures des ailes antérieures.

L'identification par le comportement indique que 5 colonies étaient FE, 6 FA et 6 Int. L'analyse morphométrique donne 10 colonies probablement européennes (Eur) et 7 probablement africanisées (Afr). Deux des colonies $F A\left(n^{\circ} 9\right.$ et 11) ont été exclues de l'analyse de la production de miel pour avoir essaimé ou déserté au cours de l'étude. La quantité moyenne de miel récoltée à partir des 15 colonies est de 41,6 kg. II n'y a pas de différence significative entre la production de miel des deux types d'abeilles, qu'elles aient été classées d'après le comportement ou d'après la morphométrie. Bien que les colonies Int aient produit plus de miel que les colonies FA ou FE, le petit nombre de colonies étudiées rend cette différence non statistiquement significative.

Les mesures de la taille des cellules correspondent plus précisément avec les identifications morphométriques, bien que les différences entre les deux types d'abeilles, lorsqu'elles sont classées par le comportement ou par la morphométrie, ne soient pas significatives. Ni le poids initial de la colonie ni la surface du couvain ne sont significativement corrélés avec la quantité de miel produit par les 15 colonies.

L'estimation du comportement est plus utile et mieux appropriée dans les régions où les abeilles africanisées ont déjà établi une population permanente et lorsque l'on souhaite sélectionner parmi un ensemble de colonies les lignées les plus douces et les plus productives. Dans ces cas-là, le degré d'africanisation n'a pas besoin d'être précisé. Le point important dans l'opération de sélection est que la colonie en question possède des caractéristiques comportementales souhaitables du point de vue de la conduite des ruches.

L'utilisation du procédé morphométrique est approprié lorsqu'il est nécessaire de détecter dans une région la présence ou l'absence de colonies africanisées, comme c'est le cas lorsque les abeilles africanisées viennent juste d'arriver dans un pays, ou pour certifier «pures" des lignées dans des régions non touchées par l'uafricanisation". On conclut que, là où les abeilles africanisées sont déjà présentes ou vont établir une population permanente, les colonies qu'il est le plus souhaitable de maintenir pour la production de miel peuvent être les colonies de comportement intermédiaire.

Apis mellifica - production de miel - abeille africanisée - Costa Rica

Zusammenfassung - Honigproduktion durch Atrikanisierte und europäische Honigbienen in Costa Rica. Die Untersuchung wurde in einer Kaffeeplantage in Costa Rica von März bis Mai 1986 durchgeführt, also ca. 3 Jahre nachdem die afrikanisierten Bienen in dieses Land gekommen sind. Die genetische Identität der Völker war am Anfang des Experiments nicht bekannt. Das Anfangsgewicht und der Brutumfang wurden vor dem HauptnektarfluB bestimmt. Jedes Volk wurde im Feld durch einen Verhaltenstest und durch Ausmessen der Größe von 10 Arbeiterinnenzellen in einer Reihe identifiziert. Unabhängig davon wurde nach Benedigung des Versuchs im Labor eine morphometrische Analyse durchgeführt.

Als Ergebnis des Verhaltenstests wurden die Völker in die Klassen «streng afrikanisiert», "streng europäisch" oder "intermediär» eingestuft. Das Kriterium für die Klassifizierung "streng afrikanisiert" war eine extreme Verteidungsbereitschaft (mehr als 10 Stiche pro Besuch) und eine hohe Irritabilität. «Streng europäische» Völker waren normalerweise sanftmütig (0-2 Stiche pro Besuch) und ruhig. Die Völker wurden als «intermediär» eingestuft, wenn sie weder immerzu defensiv noch sanft waren und die extreme Stechlust i.a. durch vorsichtige Handhabung kontrolliert werden konnte. Die Größe von 10 Arbeiterinnenzellen in einer Reihe wurde an natürlich angelegten Waben (nicht an ausgezogenen Mittelwänden) bestimmt. Das morphometrische Programm "I.D. Bees* arbeitet mit automatischer Bildanalyse auf der Basis von Messungen auf dem Vorderflügel und unterscheidet zwischen afrikanisierten und europäischen Bienen.

Die Verhaltensidentifizierung ergab, daB 5 Völker "streng europäisch" (str-E), 6 "streng afrikanisiert» (str-A) und 6 eintermediär» (Int) waren. Die morphometrische Analyse ergab, daß 10 Völker wahrscheinlich "europäisch* (Eur) und 7 wahrscheinlich *afrikanisiert» waren. Zwei der strA Völker (Nr. 9 und Nr. 11) muBten aus der Berechnung des Honigertrags ausgeschlossen werden, da sie während des Versuchs schwärmten bzw. verschwanden. Der mittlere Ertrag der restlichen 15 Völker betrug 41,6 kg. Es konnte kein signifikanter Unterschied im Honigertrag zwischen den Gruppen festgestellt werden, egal ob die Völker nach dem Verhalten oder nach der Morphometrie gruppiert wurden. Obwohl die «intermediären" Völker mehr Honig produzierten als die str-E und str- 
A Völker war diese Differenz - vermutlich aufgrund der kleinen Anzahl an untersuchten Völkern nicht signifikant.

Die Zellgrößenmessungen stimmten besser mit der morphologischen Klassifizierung überein, jedoch waren die Unterschiede zwischen den Bienentypen, weder wenn sie nach dem Verhalten noch wenn sie nach der Morphometrie klassifiziert wurden, signifikant.

Weder das Gewicht des Volkes am Anfang der Untersuchung noch der Brutumfang der 15 Völker waren mit dem Honigertrag signifikant korreliert.

Die Verhaltensidentifizierung eignet sich in Gebieten, in denen die afrikanisierten Bienen bereits seit längerem als permanente Population etabliert sind, am besten, vor allem, wenn es darum geht, aus allen Völkern die sanftmütigsten und produktivsten Linien auszuwählen. Das Ausmaß der Afrikanisierung braucht in diesem Fall nicht genau spezifiziert zu werden. Der wichtigste Punkt bei dieser Selektion ist, daß die erwünschten Verhaltenseigenschaften vom Standpunkt der Bienenhaltung her gegeben sind.

Morphometrische Analysen sind dann angebracht, wenn es notwendig ist, genau zu bestimmen, ob in einem Gebiet afrikanisierte Bienen vorkommen, also im Falle der Neubesiedlung eines Landes durch afrikanisierte Bienen, und zur Beurkundung "reiner» Bestände in Gebieten frei von "Afrikanisierung". Aus den Untersuchungen wurde geschlossen, daß es in Gebieten, in denen afrikanisierte Bienen bereits vorhanden sind, oder dabei sind, eine permanente Population zu etablieren, für die Honigproduktion am sinnvollsten ist, solche Völker zu halten, die in ihrem Verhalten intermediär sind.

Apis mellifera - Honigproduktion - afrikanisierte Honigbiene - Costa Rica

\section{Introduction}

Various comparisons have been made between Africanized and European bees as honey producers. Not surprisingly, the results are varied. Researchers and beekeepers from southern Brazil consistently report higher honey yields from Africanized than from European colonies (Cosenza, 1973; DeJong, 1984; Kerr, 1967; Michener, 1975; PortugalAraujo, 1971). In other areas of South and Central America, honey yields from Africanized colonies are reported to be either comparable to those of European bees (Rinderer et al., 1985) or lower (Anonymous, 1972; Michener, 1975; Winston et al., 1981). These discrepant reports may be a reflection of the availability of resources in the various areas, and the differential response by Africanized and European foragers to strong and weak nectar flows (Rinderer et al., 1984; 1985). Also it is important to consider whether the comparisons were made between Africanized and European bees after Africanized bees were established in an area, or whether the comparisons were made historically (i.e., do Africanized bees produce as much honey as European bees did before the arrival of Africanized bees ?) (Taylor, 1984).

Aside from these ecological and historical considerations, there are other reasons why honey production studies are confusing. The amount of honey any colony will produce is influenced by many different colony characteristics. For example, honey production has been significantly correlated with total colony population (Farrar, 1937; Woyke, 1984), short term colony weight gain (Szabo, 1982), hoarding efficiency (Kulinčević and Rothenbuhler, 1973; Milne, 1980), amount of empty comb available (Rinderer and Baxter, 1978), amount of pollen collected and corbicular area (Szabo, 1982; Milne and Pries, 1984), individual productivity and life span of worker bees (Woyke, 1981; 1984), egg laying rate and other characteristics of the queen (Moeller, 
1958; Nelson and Gary, 1983), and sealed brood areas (Soller and BarCohen, 1967; Szabo, 1982; Woyke, 1984). Heritability estimates of honey production range from 0.23 to 0.58 (Pirchner et al., 1962; Soller and BarCohen, 1967; Bar-Cohen et al., 1978).

There is also an unsubstantiated belief that larger bees produce more honey than smaller bees (Abdellatif, 1965; Grout, 1937; Jagannadham and Goyal, 1983). It has been reasoned that, since bees reared in larger than normal cells emerge as larger adults with longer tongues, the productivity of a colony could be increased by giving the colony foundation with larger cell bases. However, the implied correlation between size of European bees and overall productivity has not been verified by controlled observations.

Africanized bees are known to be, on the average, slightly smaller than European bees. They are also more defensive and thus generally more objectionable than European bees. When comparisons are made between Africanized and European types, there is a general correspondence between size and defensiveness, particularly among bees at the small and large ends of the Africanized and European ranges (Spivak et al., 1988). However, it is not clear whether there are significant correlations between size or defensive behavior and honey production.

This study describes honey production in a coffee plantation in Costa Rica from March through May, 1986, three years after Africanized bees arrived in that country. The identities of the colonies were not known at the beginning of the experiment. During the course of managing the colonies for honey production, behavioral identifications of each colony were made, and the distance spanned by 10 linear worker cells of naturally drawn comb was measured when possible. Laboratory identifications based on morphometric analyses were made independently after the termination of the study.

\section{Materials and Methods}

The experiment was conducted in the Meseta Central of Costa Rica from 1 March 1986 to 29 May 1986. Initially, 17 bee colonies were used in the study. Prior to the experiment, the colonies comprised a small unmanaged apiary located outside the town of Cartago in the Meseta Central. With the exception of 2 colonies (\# 7 and \# 9), which had been hived from swarms captured in San José in January 1986 , we had no records of any colony in the apiary. We assumed the colonies were headed by the original European queens from before the arrival of Africanized bees in Costa Rica, or by their daughters, which had presumably mated with unknown percentages of both European and Africanized drones.

In this area of Costa Rica, coffee plants (Coffea arabica) characteristically bloom $11-13$ days after the first rainfall following a prolonged dry period. This rain usually occurs at the end of February or beginning of March (in the middle of the dry season). Typically, the first bloom produces relatively few flowers, which yield low amounts of nectar. Eleven to thirteen days after the next rainfall (usually in March) the coffee blooms again. This second bloom usually produces the largest number of blossoms and yields high amounts of nectar. There may be a third bloom following another rain in April, but like the first, it usually does not yield much nectar.

On 1 March 1986, the colonies were transported from the Cartago area $(1100 \mathrm{~m}$ elevation) to the middle of a 220 hectare coffee plantation at $1800 \mathrm{~m}$ elevation on the western slope of Volcan Barva in the Meseta Central. All colonies were maintained in standard 10-frame Langstroth equipment. At the beginning of the experiment each colony occupied 1 or 2 hive bodies, and none contained more than $2-3$ frames of honey stores. The colonies were randomized and arranged in rows among the coffee plants on individual hive stands, $25 \mathrm{~cm}$ 
off the ground, and spaced at least $3 \mathrm{~m}$ apart. All colonies faced west, and were evenly shaded. The placement of the colonies in the middle of this large plantation made it likely that coffee blossoms were the primary nectar source during the coffee bloom.

In 1986, the first rain occurred on 26 February. On 5 March each colony was weighed by suspending it from a spring scale attached to a tripod. The tare weight of the box, wood of each frame, bottom board, and cover, (weighed separately for each colony) was subtracted from each colony's total weight. In this way, the weight recorded reflects only the weight of the bees, brood, wax, honey and pollen stores.

Brood area measurements were made by placing a clear sheet of plastic marked into either a 3 or $5 \mathrm{~cm}^{2}$ grid over each side of every frame containing brood. The number of squares containing unsealed (eggs and larvae) and sealed (pupae) worker brood was recorded. Also, a frame with a 2-cm 'starter strip' of wax was placed in the center of each brood nest to allow the bees to build comb (not based on foundation) so that cell size measurements could be taken at a later date. Each colony was then given 2 empty supers in which to store honey.

Samples of bees from each colony were also taken at this time. Samples were collected by gently brushing at least 100 young bees from a comb containing eggs and larvae into a cyanide jar. In this way, all bees taken were presumed to be 'nurse' bees, and not bees that might have drifted in from other colonies. Later, half of each sample was preserved in $70 \%$ ethanol, and the other half was dried. The samples are stored both in the Snow Entomological Museum, University of Kansas, and in El Museo de los Insectos, Universidad de Costa Rica.

During these manipulations, the first behavioral assessments were made by subjectively calegorizing each colony as 'strongly Africanized', 'strongly European' or 'intermediate'. The criteria for classification into the strongly Africanized category were extreme defensiveness and 'irritability' of the colony. We would receive over 10 stings per visit from these colonies through our protective clothing and gloves in the course of the management period and the bees did not remain calm on the combs. In this category, the brood pattern often covered the entire face of a brood frame. Strongly European colonies were usually docile; we would not be stung more than twice and the bees would remain relatively calm on the combs during the management period. Usually, the brood did not cover the entire face of a frame. We classified colonies as intermediate if the colony temperament was not as irritable as strongly Africanized colonies, yet not as mild as strongly European colonies. Typically, we might receive between $0-10$ stings, however we were better able to control the stinging response in these colonies through careful manipulations. In contrast, when working with strongly Africanized colonies, there seemed to be no management technique which would avoid eliciting a stinging response. The brood pattern in intermediate colonies more closely resembled that of strongly Africanized colonies and general irritability varied (see Spivak et al., 1988; Spivak, in press).

The final behavioral identification of each colony was based on the compilation of assessments made each time a colony was opened from 5 March to 29 May (5 visits). It was necessary to make repeated assessments to average out any variations in colony behavior due to weather conditions, availability of nectar, or other intra-colonial factors (such as temporary queenlessness). Also, if one or more colonies in the apiary initiated a stinging response on a particular visit, it became difficult to known whether other colonies were reacting to our manipulations or to the combination of alarm pheromone on us and the bees flying madly around the apiary.

The first coffee bloom lasted from 6-10 March. The second rain occurred on 16 March and the second, major bloom lasted from 25-30 March. The colonies were opened before the second bloom (20 March) and were given more empty supers as needed. Empty supers were placed over the brood boxes and full supers were rotated to the top (bottom supering). The colonies were weighed for a second time and bottom supered as needed again on 7 April. The last coffee bloom occurred between 25-30 April. On 15 May, the supers full of honey were removed and numbered, leaving each colony again with 1 or 2 hive bodies. Before extracting the honey, the weight of the honey in each super was recorded.

On 29 May, the colonies were inspected for the last time. On this visit, measurements of cell size were taken from the worker comb built on the empty frame previously placed in the center of the brood, nest. The mean measurement of the worker cells in the 
'naturally' built comb (i.e., comb not based on foundation) was recorded by measuring the linear distance spanned by 10 cells. In all cases, 3 diagonals of the rows of hexagonal cells were measured to average out any cell shape irregularities (see Spivak et al., 1988). No measurements were made of drone comb, comb filled with nectar or honey, or comb toward the edges of the brood nest, as these cells tend to be larger (Seeley and Morse, 1976; Taber and Owens, 1970).

Upon returning to the United States, the preserved samples were analyzed using the 'I.D. Bees' morphometric program developed by H.V. Daly for identification of workers (unpublished). Right forewings were removed from 10 bees in each sample and were measured with the aid of an automatic image analyzer and a discriminant function analysis was used to differentiate between worker types
(Batra, 1988). I.D. Bees has been repeatedly found to be reliable in tests with African and European workers of known genotype, as well as in blind tests where results were confirmed by other identification methods (Smith, 1988; Daly and Balling, 1978).

\section{Results}

The behavioral identifications of the colonies made over the course of the 5 visits (5 March, 20 March, 7 April, 15 May and 29 May) and the results of the morphometric analyses and cell size measurements are listed in Table 1. By

Table I. The amount of honey colonies produced and the identification of each colony based on behavioral assessments and morphometric analysis.

\begin{tabular}{|c|c|c|c|c|c|c|}
\hline $\begin{array}{l}\text { Colony } \\
\text { No. }\end{array}$ & $\begin{array}{l}\text { Behavioral } \\
\text { I.D. }\end{array}$ & $\begin{array}{l}\text { Morphometric } \\
\text { I.D. }\end{array}$ & $\begin{array}{l}\text { Prob. } \\
\text { sample } \\
\text { Afr. }\end{array}$ & $\begin{array}{l}\text { No. Afr. } \\
\text { workers/ } \\
\text { sample }\end{array}$ & $\begin{array}{l}\text { Cell } \\
\text { size } \\
\text { (cm) }\end{array}$ & $\begin{array}{l}\text { Honey } \\
\text { harvested } \\
\text { (kg) }\end{array}$ \\
\hline $\begin{array}{c}3 \\
17 \\
1 \\
2 \\
5\end{array}$ & $\begin{array}{l}\text { str-E } \\
\text { str-E } \\
\text { str-E } \\
\text { str-E } \\
\text { str-E }\end{array}$ & $\begin{array}{l}\text { Eur } \\
\text { Eur } \\
\text { Eur } \\
\text { Eur } \\
\text { Eur }\end{array}$ & $\begin{array}{l}0.000 \\
0.000 \\
0.010 \\
0.001 \\
0.001\end{array}$ & $\begin{array}{l}0 \\
2 \\
3 \\
1 \\
2\end{array}$ & $\begin{array}{l}5.1 \\
5.2 \\
5.2 \\
5.3\end{array}$ & $\begin{array}{l}17.1 \\
21.8 \\
25.0 \\
33.0 \\
54.5\end{array}$ \\
\hline $\begin{array}{c}14 \\
13 \\
7 \\
12 \\
10 \\
4\end{array}$ & $\begin{array}{l}\text { Int } \\
\text { Int } \\
\text { Int } \\
\text { Int } \\
\text { Int } \\
\text { Int }\end{array}$ & $\begin{array}{l}\text { Eur } \\
\text { Eur } \\
\text { Eur } \\
\text { Eur } \\
\text { Eur } \\
\text { Afr }\end{array}$ & $\begin{array}{l}0.000 \\
0.000 \\
0.000 \\
0.000 \\
0.047 \\
0.995\end{array}$ & $\begin{array}{l}0 \\
2 \\
0 \\
0 \\
2 \\
3\end{array}$ & $\begin{array}{l}5.2 \\
5.1 \\
5.1 \\
\frac{-}{5.2} \\
5.2\end{array}$ & $\begin{array}{l}30.7 \\
31.6 \\
52.5 \\
57.0 \\
64.1 \\
65.9\end{array}$ \\
\hline $\begin{array}{c}6 \\
8 \\
15 \\
16 \\
9 \\
11\end{array}$ & $\begin{array}{l}\text { str-A } \\
\text { str-A } \\
\text { str-A } \\
\text { str-A } \\
\text { str-A } \\
\text { str-A }\end{array}$ & $\begin{array}{l}\text { Afr } \\
\text { Afr } \\
\text { Afr } \\
\text { Afr } \\
\text { Afr } \\
\text { Afr }\end{array}$ & $\begin{array}{l}0.986 \\
1.000 \\
1.000 \\
0.575 \\
1.000 \\
1.000\end{array}$ & $\begin{array}{l}3 \\
6 \\
8 \\
3 \\
8 \\
5\end{array}$ & $\begin{array}{l}\overline{5.2} \\
5.1 \\
\frac{-1}{4.9} \\
5.0\end{array}$ & $\begin{array}{l}29.5 \\
33.4 \\
43.4 \\
63.4 \\
0.0^{*} \\
0.0^{*}\end{array}$ \\
\hline
\end{tabular}

The probability that a sample of 10 bees is Africanized, and the number or workers per sample that scored Africanized are calculated from the morphometric analysis. Cell size is the linear distance spanned by 10 worker cells $(n=13)$. (str-E = 'strongly European', Int = 'intermediate', str-A = 'strongly Africanized'; Afr = Africanized, Eur = European).

* Excluded from analysis of harvest means. 
behavior, we identified 5 colonies as strongly European (str-E), 6 as strongly Africanized (str-A) and 6 as intermediate (Int). The morphometric analyses indicated that 10 of these colonies were probably European (Eur) and 7 were probably Africanized (Afr). Between 5 and 20 March, colony \# 9 absconded and colony \# 11 swarmed. Both of these colonies were classified as Africanized by both behavior and morphometrics and they also had the smallest cell sizes. They are excluded from the analysis of honey production, since neither stored any honey.

The means (and standard deviations) of the amount of honey harvested from the 15 colonies (excluding colonies \# 9 and \# 11) are listed in Table II. The mean harvest for all colonies pooled was $41.6 \mathrm{~kg} ; s=16.5 \mathrm{~kg}$. When the colonies were grouped by behavior, the intermediate type $(n=6)$ produced more honey than either the strongly European ( $n=5$ ) or strongly Africanized ( $n=4$ ) types, but the differences are not significant. When the colonies were grouped by the results of the morphometric analysis, the Africanized type $(n=5)$ produced more honey than the European type $(n=10)$, but these means are also not significantly different.

Cell size measurements were obtained for 13 of the 17 colonies; the remaining 4 colonies constructed drone rather than worker comb. Colonies considered strongly European had the largest cell diameters and those strongly Africanized the smallest, although the differences between types when grouped by either behavior or by morphometric analysis are not significant (Table II).

Table II. Mean $(\bar{X})$ and standard deviations (s) of honey harvested $(\mathrm{kg})$ and measurements of cell size $(\mathrm{cm})$, when colonies are grouped by behavior and morphometric analysis.

\begin{tabular}{|c|c|c|}
\hline & Behavior & Morphometrics \\
\hline $\begin{array}{l}\text { Honey } \\
\text { Harvested } \\
\text { (kg) }\end{array}$ & $\begin{array}{ll}\text { str-E : } & \bar{X}=30.4 \\
& s=14.6 \\
\text { Int }: & \bar{X}=50.3 \\
& s=15.6 \\
\text { str-A }: & \bar{X}=42.5 \\
& s=15.2 \\
F=2.3550 \\
0.1>P>0.05\end{array}$ & 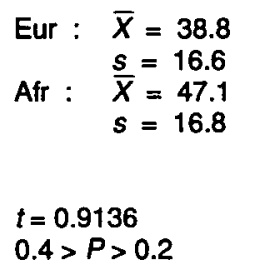 \\
\hline $\begin{array}{l}\text { Cell } \\
\text { size } \\
(\mathrm{cm})\end{array}$ & $\begin{array}{ll}\text { str-E : } & \bar{X}=5.20 \\
& s=0.08 \\
\text { Int }: & \bar{X}=5.16 \\
& s=0.05 \\
\text { str-A }: & \bar{X}=5.05 \\
& s=0.13 \\
F=2.9737 \\
0.1>P>0.05\end{array}$ & 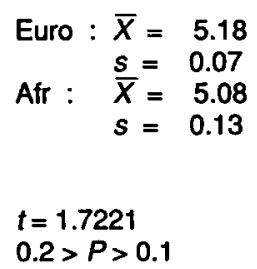 \\
\hline
\end{tabular}

(str-E = 'strongly European', $n=5$; Int = 'intermediate', $n=6 ; s t r-A=$ 'strongly Africanized', $n=4$; Eur = European, $n=10 ;$ Atr $=$ Africanized, $n=5$ ). F values from an analysis of variance, and $t$ values from $t$-test are all nonsignificant. 
The mean brood areas (unsealed, sealed and total) for all 15 colonies when sorted by behavior and bee size, are given in Table III. The brood measurements were taken on 5 March before the first coffee bloom. To help visualize the brood measurements, the entire area of one side of a frame is $800 \mathrm{~cm}^{2}$. A total brood area of $7000 \mathrm{~cm}^{2}$ corresponds to roughly 6 frames of brood, assuming the brood area actually covers about $2 / 3$ to $3 / 4$ the area of a frame. The mean brood area (total brood) for all colonies at the beginning of the study was

Table III. Means $(\bar{X})$ and standard deviations (s) of brood areas on 5 March (before first coffee bloom).

Behavior

Brood area $\left(\mathrm{cm}^{2}\right)$

Unsealed

Total

$$
\begin{array}{ll}
\text { str-E : } & \bar{X}=2700.0 \\
& s=901.8 \\
\text { Int }: & \bar{X}=3445.8 \\
& s=697.7 \\
\text { str-A : } & \bar{X}=2503.0 \\
& s=348.9
\end{array}
$$

$F=2.4093$

$$
0.25>P>0.10
$$

str-E : $\quad \bar{X}=2901.8$

$$
s=838.5
$$

Int : $\quad \bar{X}=4497.9$

$$
s=1034.5
$$

str-A : $\quad \bar{X}=3606.0$

$$
s=1707.9
$$

$F=2.4934$

$0.25>P>0.10$

$$
\begin{array}{ll}
\text { str-E : } & \bar{X}=5671.8 \\
& s=1718.4 \\
\text { Int }: & \bar{X}=7943.6 \\
\text { str-A }: & \bar{x}=1482.4 \\
\bar{X}=6109.0 \\
s=1451.3
\end{array}
$$

$F=3.2892$

$0.1>P>0.05$

\section{Morphometrics}

$t=0.1653$

$t=0.4498$

$0.9>P>0.5$

Eur : $\bar{X}=3718.4$

$s=1281.9$

Afr : $\quad \bar{X}=3747.5$

$s=1512.4$

$t=0.03915$

$P>0.9$

$$
\begin{aligned}
& \text { Eur: } \quad \bar{X}=6753.4 \\
& s=1947.7 \\
& \text { Afr : } \quad \bar{X}=6585.0 \\
& s=1646.5
\end{aligned}
$$

$0.9>P>0.5$

Colonies are sorted by behavior and morphometric analysis. All $F$ values (from analysis of variance) and $t$ values (t-test) are non-significant. Unsealed brood = eggs and larvae; sealed = pupae; total = unsealed + sealed. 
$6697.3 \mathrm{~cm}^{2}$, or approximately 6 frames of brood, and ranged from 3 to 9 frames. When the colonies were sorted by morphometrics, both Africanized and European colonies maintained very similar brood areas. When the colonies were sorted by behavior, however, the intermediates maintained greater brood areas than those colonies considered either strongly Africanized or strongly European, although the differences were not significant.

The mean weight of the colonies before (5 March) and after (7 April) the major nectar flow and the mean weight gain between these two readings are recorded in Table IV. During the main nectar flow, all colonies increased in

Table IV. The mean $(\bar{X})$ and the standard deviation (s) of colony weights $(\mathrm{kg})$ on 5 March (before the first coffee bloom), 7 April (after the major nectar flow), and the weight gained between the two readings.

Behavior

Colony weight

5 March

7 April

Weight gain

$$
\begin{aligned}
& \text { str-E : } \quad \bar{X}=51.7 \\
& s=19.7 \\
& \text { Int: } \quad \bar{X}=80.0 \\
& s=23.1 \\
& \text { str-A : } \bar{X}=53.6 \\
& s=21.0 \\
& F=2.9320 \\
& 0.1>P>0.05
\end{aligned}
$$

\section{Morphometrics}

$$
\text { Eur : } \begin{aligned}
& \bar{X}=31.8 \\
&=9.9 \\
& \text { Afr }: \quad \quad \bar{X}=33.3 \\
& s=11.3 \\
& \\
& t=0.2719 \\
& 0.9>P>0.5
\end{aligned}
$$

Eur: $\quad \begin{aligned} \bar{X} & =95.4 \\ & s=23.3 \\ \text { Afr }: & \bar{X}=95.9 \\ & \quad s=35.9\end{aligned}$

$t=0.0090$

$P>0.9$

Eur : $\quad \bar{X}=64.0$

Afr : $\quad \bar{X}=62.6$

$s=27.0$

The weights do not include the weight of the box, bottom board, cover or wood in the frames. All $F$ values ffrom analysis of variance) and $t$ values ( $t$-test) are non-significant. 
weight substantially; however, some of the lighter colonies gained more than the heavier ones. For example, colony \# 2 was initially the second heaviest colony $(42.2 \mathrm{~kg})$ and ultimately gained $49.5 \mathrm{~kg}$. Colony \# 10 was the second lightest colony $(19.3 \mathrm{~kg})$ but gained $104.3 \mathrm{~kg}$, more than any other colony. When the colonies were grouped by morphometrics, the mean initial and final weights for both Africanized and European colonies were similar. When grouped by behavior, the 3 types had similar initial weights, but the intermediates gained $27.3 \mathrm{~kg}$ more than the Africanized and European behavioral groups, although again, the differences between them were not significant.

Correlations (Pearson productmoment) between honey harvested, initial brood areas and colony weights are given in Table V. Since the sample sizes are small when the colonies are sorted by types (making any significant correlations dubious), only the coefficients for the 15 pooled colonies are given.

\section{Discussion}

The results of this study show that in this habitat and under these resource conditions, small bees produced as much honey as large bees and defensive colonies produced as much honey as gentle colonies. Although there was a tendency for intermediate colonies to produce more honey than both strongly Africanized or strongly European colonies, the small number of colonies studied made this difference statistically nonsignificant. Another consideration in the interpretation of these results is the difficulty involved in managing, for honey production, colonies which are extremely defensive and have a high tendency to swarm and abscond (colonies \# 9 and \# 11 of this study). If these colonies had not been excluded from the analysis, the mean amount of honey harvested from the Africanized colonies (whether sorted by behavior or morphometrics) would have been considerably lower.

No significant correlation was found between honey production and brood area, or colony weight (Table V). It is difficult to determine if the lack of correlation was due to the small sample sizes and variation in initial brood areas and colony weights, or whether a combination of intra-colonial and environmental factors are more important in determining how much honey a colony can produce (see Malkov and Sedykh, 1980; Rinderer et al., 1984; Szabo, 1980; 1982; Woyke, 1981; 1984).

Table V. Correlation coefficients ( $r$, Pearson product-moment) between honey harvested, initial weights and brood areas measured on 5 March, all colonies pooled, $n=15$ ).

\begin{tabular}{lllll}
\hline & $\begin{array}{l}\text { Initial } \\
\text { weight } \\
(\mathrm{kg})\end{array}$ & $\begin{array}{l}\text { Total } \\
\text { brood } \\
\mathrm{cm}\end{array}$ & $\begin{array}{l}\text { Unsealed } \\
\text { brood } \\
\mathrm{cm}\end{array}$ & $\begin{array}{l}\text { Sealed } \\
\text { brood } \\
\mathrm{cm}^{2}\end{array}$ \\
\hline $\begin{array}{l}\text { Honey } \\
\text { harvested }\end{array}$ & $\begin{array}{l}r=0.1695 \\
P>0.05\end{array}$ & $\begin{array}{l}r=0.3177 \\
P>0.05\end{array}$ & $\begin{array}{l}r=0.1689 \\
P>0.05\end{array}$ & $\begin{array}{l}r=0.3354 \\
P>0.05\end{array}$ \\
\hline
\end{tabular}

All $r$ values are non-significant. 
The measurements of cell size in this study indicated that most of the colonies were within the European range. European honey bees in the United States, Canada and the neotropics build worker brood cells (without the use of foundation) in which a series of 10 cells averages from 5.2 to $5.3 \mathrm{~cm}$ (range = 5.0-5.4 cm; Rinderer et al., 1986a). The average measurements of 10 linear cells of Africanized bees in the neotropics are 4.8 and $4.9 \mathrm{~cm}$ (range $=4.6-5.0 \mathrm{~cm}$; Barbosa da Silva and Newton, 1967; Cosenza and Batista, 1973; Rinderer et al., 1986a). Colonies with 'intermediate' behavioral characteristics also tend to have intermediate cell sizes (between 4.9 and $5.2 \mathrm{~cm})$, although the correspondence is not consistent (Spivak et al., 1988).

The cell size measurements of this study correspond more closely to the results of the morphometric analysis than to the behavioral identification (Table 1). This correspondence is to be expected if the size of a bee is influenced by the size of the cell in which it is reared (see Rinderer et al., 1986b) and if behavior is not necessarily correlated with size. One of the problems with using cell size as an indicator of colony type is that it is not known how much of the variation in cell size is influenced by genetic and how much by environmental factors. For example, resource availability, colony size and ambient temperature affect comb construction (Szabo, 1977) which probably influences cell size and the size of the bees reared in those cells. But it is not known whether bees reared in large cells will subsequently build larger cells. Preliminary observations (M. Spivak, unpublished data) indicated that small (Africanized) bees reared in larger (European) sized cells later built cells which measured in the Africanized range. The reverse case, of European bees reared in small cells and later building large cells, was also seen.

This study raises important questions for beekeepers who work in areas where Africanized bees are currently found or are likely to thrive. If a particular colony is not excessively defensive, responds to swarm control measures and produces large amounts of honey, yet a morphometric analysis indicates that is Africanized, should the colony be requeened or eliminated in an attempt to maintain 'pure' European bees ? When is it appropriate to use a morphometric analysis to identify colonies and when is it more appropriate to assess colonies solely on the basis of behavior ? (For related discussions, see Page and Erickson, 1985; and Page et al., 1987).

Behavioral assessments are most useful and appropriate in areas where Africanized bees have already established a permanent population and when it is desirable to select among all colonies (whether Africanized, European or intermediate) for the most gentle and productive lines. In these areas, it is not feasible to maintain a 'pure' European population (as characterized by morphometrics or other identification procedures) in commercial apiaries due to potential gene flow with the feral Africanized population (Taylor, 1985; 1988). The mixing of the 2 populations results in the inability to accurately classify those colonies whose size (or other characteristic) falls between extremes of the Africanized and European ranges (see Page and Erickson, 1985). The advantage of classifying colonies by behavior is that the level or degree of 'Africanization' does not need to be specified. Referring to a colony as an 'intermediate' does not specify information about its genetic background or size of the bees, since an intermediate colony may be headed by a queen of European, 
Africanized or mixed ('hybrid') descent. The important point is that the colony in question has desirable behavioral attributes from a management standpoint.

The use of a morphometric procedure such as 'I.D. Bees' is appropriate when it is necessary to detect the presence or absence of Africanized colonies in an area, as when Africanized bees are just arriving in a country and for the certification of 'pure' stocks in areas free of 'Africanization'. As currently used, the analysis categorizes bee samples into 2 groups : 'probably Africanized' and 'probably European'. These categories, however, do not consistently correspond with behavioral assessments or other identification techniques (Spivak et al., 1988).

In conclusion, in places where Africanized bees are already present or will establish a permanent population in the future, the most desirable colonies to maintain for honey production may be the behavioral intermediates. It is not feasible or even necessary to specify "how Africanized' a particular colony is when the feral population is Africanized and queens from commercial apiaries are allowed to mate naturally. The easiest way for beekeepers to maintain colonies with intermediate behavioral characteristics is through consistent selection for the most gentle and productive bees by requeening the most defensive colonies and rearing queens and drones from the most gentle colonies. Certified queens from areas free of Africanized bees (which could be verified appropriately through morphometric analysis) could be introduced into areas with Africanized bees to facilitate the selection process.

\section{Acknowledgments}

We thank the Ruiz family for allowing us to place our colonies in their coffee plantation. E.
Erickson, C. Gentry, C.D. Michener, O.R. Taylor, J. Villa and W.T. Wcislo provided valuable comments on the manuscript. This research was funded by an NSF Dissertation Improvement Grant no. BSR-8313554, a Fellowship from the Organization of American States no. 594908 and the beekeepers who took part in the 'Speedy Bee Tour' through Central America in 1985 (to M.S.).

This is contribution \# 2032 from the Department of Entomology, University of Kansas, Lawrence, KA, USA.

\section{References}

Abdellatif M.A. (1965) Comb cell size and its effect on the body weight of the worker bee, Apis mellifera L. Am. Bee J. 105, 86-87

Anonymous (1972) Final Report, Committee on the African honeybee. Nat. Res. Counc. Natt. Acad. Sci., Washington D.C., pp. 95

Barbosa da Silva R.M. \& Newton S.W. (1967) Sobre a bionomia da Apis Afro-europei do Brasil. Bol. de Ind. Anim. 24 N.S. Unico-Sao Paulo, Brasil. pp. 199-208

Bar-Cohen R., Alpern G. \& Bar-Anan R. (1978) Progeny testing and selecting Italian queens for brood area and honey production. Apidologie 9, 95-100

Batra S.W.T. (1988) Automatic image analysis for rapid identification of Africanized honey bees. In : Africanized Honey Bees and Bee Mites (Needham G.R., Page R.E. Jr., Delfinado-Baker M. \& Bowman C.E., eds.), Ellis Horwood Ltd., Chichester, pp. 260-263

Cosenza G.W. (1973) Comparaçăo entre a produtividade da abelha africana, da abelha caucasiana e de suas híbridas. 2nd Congr. Bras. Apic. (Sete Lagoas, 1972) pp. 50-52

Cosenza G.W. \& Batista J.S. (1973) Morfometría da Apis mellifera adansonii (abelha africanizada) da Apis mellifera caucasica (abehla caucasiana) e suas híbridas. 2nd Congr. Bras. Apic. (Sete Lagoas, 1972) pp. 53-56

Daly H.V. \& Balling S.S. (1978) Identification of Africanized honey bees in the western hemisphere by discriminant analysis. J. Kans. Entomol. Soc. 51, 857-869

DeJong D. (1984) Africanized bees now

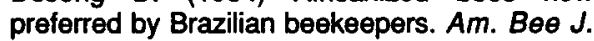
124, 116-118 
Farrar C.L. (1937) The influence of colony populations on honey production. J. Agric. Res. (Wash D.C.) 54, 945-954

Grout R.A. (1937) The influence of size of brood cell upon the size and variability of the honeybee (Apis mellifera L.) Agric. Exp. Stn. Res. Bull. 218, 257-280

Jagannadham B. \& Goyal N.P. (1983) Morphological and behavioural characteristics of honey bee workers reared in combs with larger cells. Proc. 2nd Int. Conf. on Apiculture in Tropical Climates, New Delhi 1980, 238-253

Kerr W.E. (1967) The history of the introduction of African bees to Brazil. S. Afr. Bee J. 39, 3-5

Kulinčević J.M. \& Rothenbuhler W.C. (1973) Laboratory and field measurements of hoarding behaviour in the honeybee. J. Apic. Res. 12, 179-182

Malkov V.V. \& Sedykh A.V. (1980) Selection of bee colonies for productivity under relatively poor honey flow conditions. Apiacta 15, 66-69

Michener C.D. (1975) The Brazilian bee problem. Annu. Rev. Entomol. 20, 399-416

Milne C.P. Jr. (1980) Laboratory measurement of honey production in the honeybee. 1. A model for hoarding behaviour by caged workers. J. Apic. Res. 19, 122-126

Milne C.P. Jr. \& Pries K.J. (1984) Honeybee corbicular size and honey production. J. Apic. Res. 23, 11-14

Moeller F.E. (1958) Relation between egglaying capacity of queen bee and populations and honey production of their colonies. $A m$. Bee J. 98, 401-402

Nelson D.L. \& Gary N.E. (1983) Honey productivity of honeybee colonies in relation to body weight, attractiveness and fecundity of the queen. J. Apic. Res. 22, 209-213

Page R.E. Jr. \& Erickson E.H. Jr. (1985) Identification and certification of Africanized honey bees. Ann. Entomol. Soc. Am. 78, 149158

Page R.E. Jr., Nash E.R. \& Erickson E.H. Jr. (1987) Use of honey yield data to assess damage to the beekeeping industry of the United States. Bull. Entomol. Soc. Am. 33, 190194

Pirchner F., Ruttner F. \& Ruttner H. (1962) Erbliche unterschiede zwischen Ertagsegenschaften von Bienen. Proc. 11th Int. Congr. Entomol. 11, 501-516

Portugal-Araujo V. de (1971) The Central African bee in South America. Bee World 52, 116-121
Rinderer T.E. \& Baxter J.R. (1978) Effect of empty comb on hoarding behavior and honey production of the honeybee. J. Econ. Entomol. 71, 757-759

Rinderer T.E., Bolten A.B., Collins A.M. \& Harbo J.R. (1984) Nectar-foraging characteristics of Africanized and European honeybees in the neotropics. J. Apic. Res. 23, 70-79

Rinderer T.E., Collins A.M. \& Tucker K.W. (1985) Honey production and underlying nectar harvesting activities of Africanized and European honeybees. J. Apic. Res. 24, 161-167

Rinderer T.E., Sylvester H.A., Brown M.A., Villa J.D., Pesante D. \& Collins A.M. (1986a) Field and simplified techniques for identifying Africanized and European honey bees. Apidologie 17, 33-48

Rinderer T.E., Sylvester H.A., Collins A.M. \& Pesante D. (1986b) Identification of Africanized and European bees : effects of nurse-bee genotype and comb size. Bull. Entomol: Soc. Am. 32, 150-152

Seely T.D. \& Morse R.A. (1976) The nest of the honey bees (Apis mellifera L.) Insectes Soc. 23, 495-512

Smith R.K. (1988) Identification of Africanization in honey bees based on extracted hydrocarbons assay. In : Africanized Honey Bees and Bee Mites (Needham G.R., Page R.E. Jr., Delfinado-Baker M. \& Brown C.E., eds.), Ellis Horwood Ltd., Chichester, pp. 275280

Soller M. \& Bar-Cohen R. (1967) Some observations on the heritability and genetic correlation between honey production and brood area in the honeybee. J. Apic. Res. 6, 37-43

Spivak M. (1989) The Africanization process in Costa Rica. In : The "African" Honey Bee (Breed M. \& Fletcher D.J.C., eds.), Westview Press, Boulder, $\mathrm{CO}$, in press

Spivak M., Ranker T., Taylor O.R., Taylor W. \& Davis L. (1988) Discrimination of Africanized honey bees using behavior, cell size, morphometrics, and a newly discovered isozyme polymorphism. In : Africanized Honey Bees and Bee Mites (Needham G.R., Page R.E. Jr., Delfinado-Baker M., Bowman C.E.), Ellis Horwood Ltd., Chichester, pp. 313-325

Szabo T.I. (1977) Effect of colony size and ambient temperature on comb building and sugar consumption by honeybees. J. Apic. Res. 16, 174-183

Szabo T.I. (1980) Effect of weather factors on honeybee flight activity and colony weight gain. J. Apic. Res. 19, 164-171 
Szabo T.I. (1982) Phenotypic correlations between colony traits in the honey bee. Am. Boo J. 122, 711-716

Taber S. III \& Owens C.D. (1970) Colony founding and initial nest design of honey bees, Apis mellifera L. Anim. Behav. 18, 625-632

Taylor O.R. (1984) Challenges Africanized bee article. Am. Bee J. 124, 395-396

Taylor O.R. (1985) African bees : potential impact in the United States. Bull. Entomol. Soc. Am. 31, 14-24

Taylor O.R. (1988) Ecology and economic impact of African and Africanized honey bee. In : Atricanized Honey Bees and Ber Mites
(Needham G.R., Page R.E. Jr., DelfinadoBaker M. and Bowman C.E., eds.), Ellis Horwood Ltd., Chichester, pp. 29-44

Winston M.L., Dropkin J.A. \& Taylor O.R. (1981) Demography and life history characteristics of two honey bee races (Apis mellifera). Oecologia 48, 407-413

Woyke J. (1981) Influence of colony internal factors on honey production in El Salvador. 28th Int. Congr. Apic. Acapulco, pp. 288-304

Woyke J. (1984) Correlations and interactions between population, length of worker life and honey production by honeybees in a temperate region. J. Apic. Res. 23, 148-156 